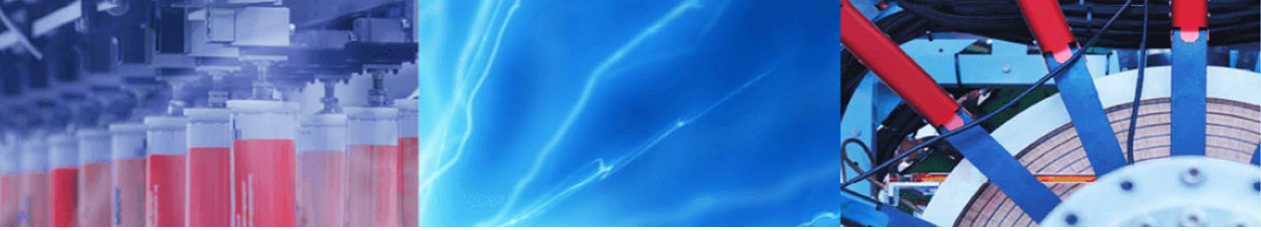

Research Article

\title{
Enzymatic synthesis of cinnamyl propionate from cinnamyl alcohol and propionic acid in a solvent free condition
}

\author{
Meera T. Sose ${ }^{1}$. Sarita D. Gawas ${ }^{1}$. Virendra K. Rathod ${ }^{1}$
}

Received: 31 December 2019 / Accepted: 26 March 2020 / Published online: 8 April 2020

(c) Springer Nature Switzerland AG 2020

\begin{abstract}
This work illustrates the synthesis of cinnamyl propionate in the presence of lipase biocatalyst. The esterification reaction was performed in a solvent free condition with cinnamyl alcohol and propionic acid using fermase CALB ${ }^{\mathrm{TM}} 10000$, a commercial lipase. Experiments were conducted to study different operating parameters such as enzyme loading, temperature, mole ratio, speed of agitation, and reusability of enzyme. Various kinetic parameters affecting esterification reaction were evaluated to synthesize cinnamyl propionate. It has been observed that the data obtained follows random bi-bi mechanism with inhibition by both acid and alcohol substrate. The highest conversion of cinnamyl propionate obtained is $87.89 \%$ after $7 \mathrm{~h}$ at optimum parameters: enzyme loading $2 \%(\mathrm{w} / \mathrm{v})$, temperature $60^{\circ} \mathrm{C}$, acid to alcohol ratio $1: 3$, molecular sieves $6 \%(\mathrm{w} / \mathrm{v})$ and agitation speed $200 \mathrm{rpm}$. Limitation of diffusion mass transfer between the enzyme surface and substrate does not show a significant effect on reaction kinetics. The study of repeated use of enzyme shows that it maintains $90 \%$ of its catalytic activity after six successive batches.
\end{abstract}

Keywords Esterification · Cinnamyl propionate · Enzymatic catalysis · Lipase · Kinetics · Ping-pong bi-bi mechanism

\section{Introduction}

The sweet aroma esters are short-chain compounds usually used in food products like squashes, beverages, jams, candies, jellies, syrup, chocolates, ice-creams, and dairy products as a flavoring agent [1]. Similarly, the fatty acids derived long-chain esters are generally used in pharmaceuticals, cosmetics, surfactants [2], and also in lubricants, plasticizers, water-resistant agents, diesel additives, hydraulic fluids as reaction medium [3, 4]. Likewise, several esters of short-chain fatty acid, demonstrate fruity odor characteristic, which include ethyl butyrate (strawberry or pineapple flavor) [5], 1-methyl butyrate (apple or pineapple flavor) [6], butyl butyrate [7], ethyl hexanoate (pineapple flavor) [8], isoamyl isovalerate (apple flavor) [9], isoamyl acetate [10] and (banana flavor) isoamyl butyrate [10,11]. The several cinnamyl esters having aroma characteristics are used in personal care products. In previous literature, cinnamyl acetate is synthesized by trans-esterification of vinyl acetate and cinnamyl alcohol. This reaction can be carried out by either chemical or biochemical, with the enzyme as a bio-catalyst $[12,13]$. Lipases are well-known as catalyst for esterification, transesterification, and hydrolysis [8].

Cinnamyl propionate is a vital ingredient used for formulation in perfume mostly in oriental fragrance type as a modifier for the more pronounced, spicy items. It blends with Oak moss into a very pleasant composition, particularly in the presence of clove bud, bay leaf oil, etc. and has wide range applications as intermediate in the synthesis of fine chemicals drugs, plasticizers, cosmetics, flavor, and fragrances. Similarly, work reported by Geng et al. [14] proves the toxicological and dermatological outcome of cinnamyl butyrate along with some other esters of cinnamyl.

$\triangle$ Virendra K. Rathod, vk.rathod@ictmumbai.edu.in | 'Department of Chemical Engineering, Institute of Chemical Technology, Matunga (E), Mumbai 400019, India. 
Cinnamyl butyrate can be considered as a substitute for cinnamyl propionate as it indicates almost the same kind of results in the investigations. Naturally, this flavor can be found in tea-tree leaves, fresh cinnamon bark, daffodil flower, and hyacinth and pink guava fruit.

Synthesis of value added ester by enzyme catalyzed reaction was found to be better than other traditional systems for ester cinnamyl propionate. The International legislation has defined that "Natural" flavor and fragrances can only be prepared either by enzymatic, microbial processes or natural sources extraction by using physical processes [15]. So, enzyme catalyzed esterification reactions is one of the best alternatives to chemical catalyzed synthesis. Enzyme catalyzed synthesis has certain advantages as it takes place at mild conditions and gives pure product than the chemical methods. As enzymes have specificity towards the substrate, and no by-products are formed, it helps to reduce overall production cost $[16,17]$. In India, the approximate market value of cinnamyl propionate is Rs. 28,000 per Liter. Worldwide consumption of cinnamyl propionate is different in chemical industries, and it may be about 100 metric tons per annum [16]. Thus, there is a huge demand for the cinnamyl propionate synthesized by the enzymatic route. Moreover, the bio-catalyst also helps to make the process cost effective by repeated reuse of the same enzymes. Additionally, the immobilized enzyme exhibits good stability towards the harsh reaction conditions, such as $\mathrm{pH}$ range and temperatures, without weakening its activity [12]. Further, water obtained from esterification reaction leads to hydrolysis that gives way back the substrate (as esterification is a reversible reaction). Therefore, controlling the backward reaction of hydrolysis by using molecular sieves as water adsorbent is necessary to push the reaction forward and achieve the desired conversion of ester. In this context, a work reported by Yadav and Dhoot [18] used Novozym 435 enzyme with conversion $60 \%$, at $30^{\circ} \mathrm{C}$ temperature in $2 \mathrm{~h}$ for equimolar quantities of the reactants using $0.33 \%(\mathrm{w} / \mathrm{v})$ of catalyst to synthesis of cinnamyl laurate. They observed that the dead-end complex of lauric acid represented the kinetic data for an ordered bi-bi mechanism [18]. However, vast literature reports indicated that there is not a single attempt made to synthesis cinnamyl propionate in solvent-free conditions using an enzyme. This is the first attempt to synthesis cinnamyl propionate ester with immobilized lipase in a stirred batch reactor. Thus, the objective of the present work is to optimize the reaction parameters for the synthesis of spicy flavor cinnamyl propionate ester using Candida antarctica, commercially known as Fermase CALB ${ }^{\text {TM }} 10000$. The process reaction parameters studied are temperature, substrate molar ratio, concentration of enzyme loadings and speed of agitation. Several bi-substrate models have been advised to explain the esterification reaction kinetics catalyzed by lipase $B$.

\section{Materials and methods}

\subsection{Materials and enzymes}

Fermase CALB ${ }^{\mathrm{TM}} 10000$ from Candida antarctica was kindly provided as a gift sample by Fermenta Biotech. Pvt. Ltd; Mumbai. The initial activity of the immobilized enzyme Fermase is $9.15 \mathrm{U}$ (particle size $150-300 \mu \mathrm{m}$, pore volume of $1.32 \mathrm{~cm}^{3} / \mathrm{g}$, bulk density of $0.54 \mathrm{~g} / \mathrm{cm}^{3}$ ). The activity of enzyme was expressed as $1 \mu \mathrm{mol}$ of propionic acid utilized per $\mathrm{mg}$ of enzyme per min in the reaction. Propionic acid and cinnamyl alcohol were purchased from S.D. Fine Chemicals Pvt. Ltd., Mumbai, India. Other chemicals such as ethanol AR-grade, methanol AR-grade, and potassium hydroxide pellets were purchased from Thomas Baker Pvt. Ltd., Mumbai, India. The molecular sieves ( $3 \AA$ ) were purchased from Ranco Chemicals, Mumbai. All chemicals and enzymes were used without further modification.

\subsection{Experimental setup}

For the synthesis of cinnamyl propionate ester, the experimental set up consisted of a glass reactor with $50 \mathrm{~mL}$ capacity covered with lid having three necks to attach various accessories such as a condenser for reflux and overhead mechanical stirrer with four blade impellers. The complete assembly of the reactor with the substrate was immersed in a thermostatic water bath, and the desired temperature was maintained with an accuracy of $\pm 1^{\circ} \mathrm{C}$. To perform the enzymatic reaction, a measured amount of substrate with a known molar ratio of cinnamyl alcohol to propionic acid i.e. $19.35 \mathrm{~mL}(0.149 \mathrm{~mol})$ of cinnamyl alcohol and propionic acid $3.75 \mathrm{~mL}(0.050 \mathrm{~mol})$ for $3: 1$ ratio, were added to the reactor at temperature $60^{\circ} \mathrm{C}$. Further, 2\% (w/v) of immobilized lipase B based on the total volume of the substrate was added to start the reaction with an agitation speed $200 \mathrm{rpm}$ along with molecular sieves $6 \%(\mathrm{w} / \mathrm{v})$ of the total volume of substrates to prevent hydrolysis by water produced during the reaction. The total volume of the reaction was maintained $23.08 \mathrm{~mL}$ (alcohol $19.35 \mathrm{~mL}$ and $3.75 \mathrm{~mL}$ acid) throughout the reaction process, and no other solvent was added. Several samples were drawn at a particular time interval to determine the acid value and subsequently, the percent ester conversion. All experiments were performed in duplicate or triplicate, and average values have been reported. It has been observed that the maximum deviation from the mean was less than $5 \%$ in most of the experiments. 


\subsection{Analysis method}

\subsubsection{Acid value determination}

The percentage (\%) ester conversion of cinnamyl propionate was determined by measuring the unreacted propionic acid remaining in the reaction mixture by titration method [19]. A sample of liquid was collected during the reaction and analyzed by a titration method. This method involves taking a known weighed amount of the sample into a conical flask and titrating with $0.1 \mathrm{~N} \mathrm{KOH}$ [20] standardized solution with an addition of phenolphthalein indicator and ethanol as a quenching agent. The standardized values of $0.1 \mathrm{~N} \mathrm{KOH}$ were used to determine the acid value of ester cinnamyl propionate using the following Eq. 1.

Acid value $(A V)=\frac{56.1 \times N \times V}{W}$

where $\mathrm{N}=\mathrm{KOH}$ solution normality used, $\mathrm{V}=\mathrm{KOH}$ volume required to neutralize the acid in $\mathrm{mL}, \mathrm{W}=$ sample weight in grams for analysis. The percentage conversion of ester can be calculated by the following Eq. 2,

Conversion $(\%)=\frac{\text { Initial acid value }- \text { Current acid value }}{\text { Initial acid value }} \times 100$

The samples were also analyzed using gas chromatography (GC) method reported earlier [6]. Since the conversion obtained using both these methods was almost similar, the titration method was used to determine the conversion in all the experiments.

\subsubsection{Enzyme reusability study}

The study for the repeated reuse of enzyme was also conducted to analyze the catalytic activity of the biocatalyst at optimized reaction conditions. After each batch run, the enzymes were separated by simple filtration method, and washed with hexane and thereafter dried for $60 \mathrm{~min}$ in an oven at $40^{\circ} \mathrm{C}$ temperature and then reused for the subsequent batch.

\subsubsection{Product purification}

After the reaction, the reaction mixture was filtered through Whatman paper to remove the immobilized enzyme and molecular sieve. The unreacted propionic acid in the reaction mixture was neutralized with $\mathrm{Na}_{2} \mathrm{CO}_{3}$, and the traces of formed salt were removed by several water washings. Anhydrous $\mathrm{MgSO}_{4}$ was added to the remaining mixture as a drying agent to remove the water from the mixture [21, 22]. The residual cinnamyl alcohol was further removed by vacuum distillation.

\subsubsection{NMR characterization}

The purified product was dissolved in $500 \mu \mathrm{L}$ deuterated chloroform $\left(\mathrm{CDCl}_{3}\right)$. The spectra were recorded using a $400 \mathrm{MHz}$ at $25^{\circ} \mathrm{C}$.

\subsubsection{Kinetic constant determination}

The kinetic constant of enzymatic esterification reaction for the synthesis of cinnamyl propionate ester using cinnamyl alcohol and propionic acid was determined at several concentrations of acid and alcohol. Aliquots of the reaction mixture were taken sequentially and analyzed by titrimetric analysis, as discussed above. Conversion data for $<10 \%$ conversion was used to determine initial reaction rates by plotting conversion versus time profiles. Experiments were carried out by keeping the concentration of one of the substrates constant and was carried out in solvent free system either specific or random manner to form a complex varying the concentration of the other and vice versa. Further, bi substrate kinetic models like ping pong bi-bi, ordered bi-bi and random bi-bi were used to evaluate the kinetic data obtained from the synthesis of cinnamyl propionate ester.

\section{Results and discussion}

\subsection{Effect of molar ratio}

The product conversion and rate of reaction depend on the substrate concentration. While synthesis of cinnamyl propionate ester through enzymatic esterification reaction, the amount of cinnamyl alcohol plays a considerable role in the conversion of propionic acid to ester. Here, the substrate mole ratios of propionic acid to cinnamyl alcohol considered were 1:1, 1:2, 1:3 and 1:4. The propionic acid acts as a limiting reagent, and hence its volume was kept constant. These experiments were conducted at temperature $60{ }^{\circ} \mathrm{C}$, enzyme loading $2 \%(\mathrm{w} / \mathrm{v})$ of total substrate, speed of agitation $200 \mathrm{rpm}$. The results depicted in Fig. 1 describes that the maximum conversion of ester cinnamyl propionate was $87.89 \%$ at $1: 3$ substrate molar ratios. It was noticed that as the concentration of alcohol increased by changing ratio from 1:1 to $1: 3$, the final conversion also increased from 62.77 to $87.89 \%$, respectively. Patidar and Mahajani [23] observed that excess alcohol favored the synthesis 


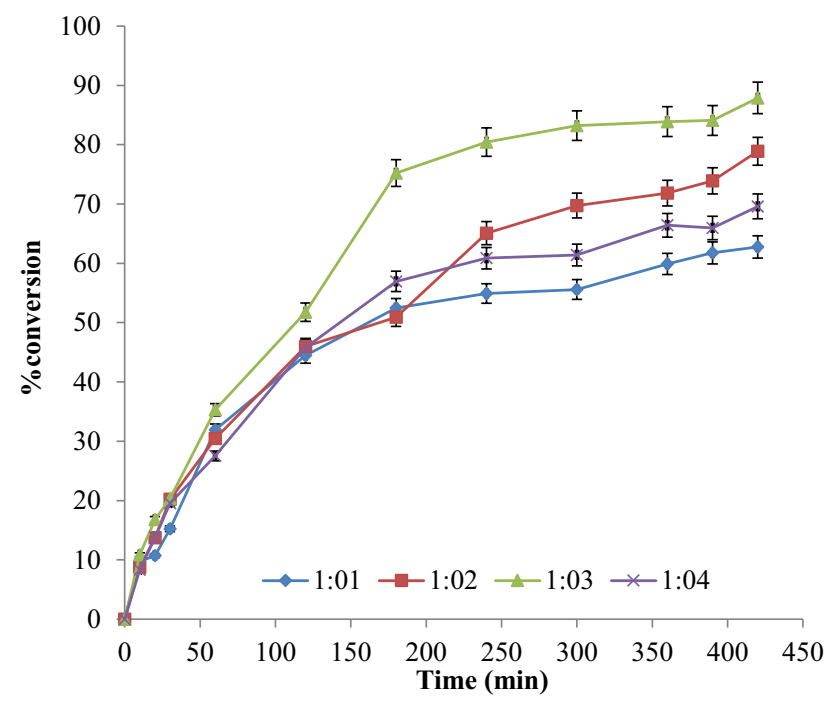

Fig. 1 Effect of mole ratio concentration of propionic acid: cinnamyl alcohol: reaction conditions: temperature $60^{\circ} \mathrm{C}$, total volume is $23.08 \mathrm{~mL}$, enzyme loading $2 \%(\mathrm{w} / \mathrm{v})$, speed of agitation $200 \mathrm{rpm}$; and molecular sieves $6 \%(\mathrm{w} / \mathrm{v})$

of isoamyl propionate with molar ratio 1:2 of propionic acid to isoamyl alcohol. However, a further increase in the amount of alcohol i.e., mole ratio 1:4 decreases the ester conversion to $69.59 \%$. This decrease in the ester conversion and reaction rate with excess cinnamyl alcohol concentration could be attributed to the inhibition of an enzyme by solvent. The alcohols are hydrophilic in nature that causes the natural conformation with enzyme and declines the ester formation. The propionic acid is limiting reactant and being polar in nature helps to maintain the water molecules on the enzyme structure. On the other hand, excess cinnamyl alcohol may reduce this deposited hydration owing to its higher affinity towards water molecules. Thus, in this case, alcohol may be performing as an enzyme terminal inhibitor and an increase in the amount of propionic acid may cause strong diffusion limitation due to acid inhibition, i.e. acid can gradually deactivate the enzyme by dropping $\mathrm{pH}$ at the micro-environment as propionic acid being polar in nature. The enzyme binds with acid to form acyl enzyme complex, this formed complex if fails to dissociate, converts in a dead end-complex or cannot yield ester contributing to the inhibitory action of acid, which could also decrease the ester conversion and rate of reaction in synthesis owing to its high viscosity. The initial rate of reaction is directly affected by increasing the cinnamyl alcohol ratio. A little excess alcohol favors enzymatic esterification reaction. Hence, 1:3 mol ratio of the substrates propionic acid to cinnamyl alcohol was optimum and kept constant throughout the synthesis of ester in the enzymatic reaction process.

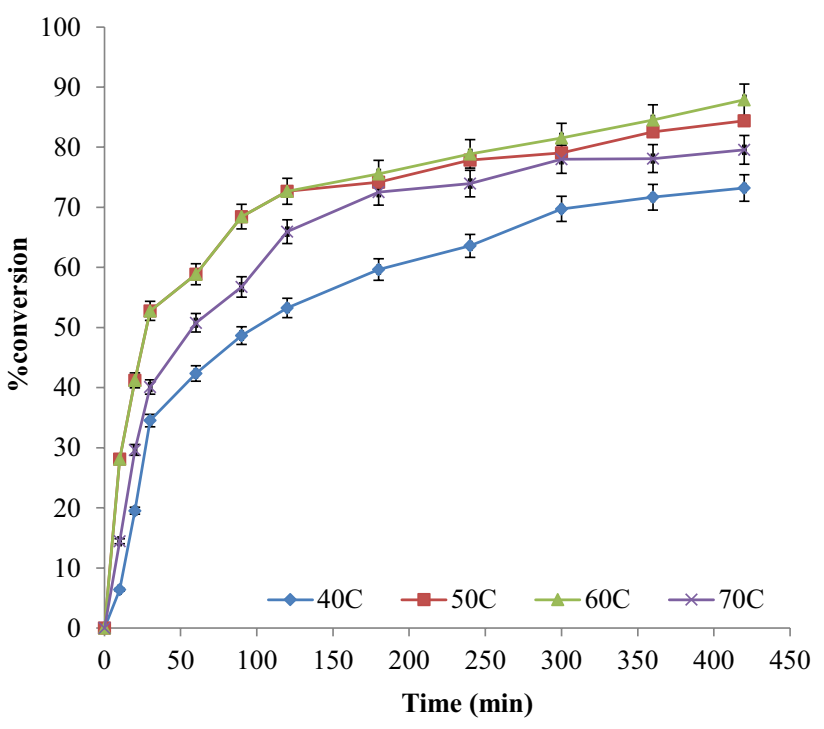

Fig. 2 Effect of temperature on conversion of cinnamyl propionate: reaction conditions: molar ratio $1: 3$, total volume is $23.08 \mathrm{~mL}$, enzyme loading $2 \%(\mathrm{w} / \mathrm{v})$, speed of agitation $200 \mathrm{rpm}$; and molecular sieves $6 \%(\mathrm{w} / \mathrm{v})$

\subsection{Effect of temperature}

The temperature effect on ester conversion was studied by varying the temperature from 40 to $70^{\circ} \mathrm{C}$ while keeping the other reaction parameters constant. Figure 2 shows that the ester cinnamyl propionate conversion increases from 69.59 to $87.89 \%$ as the temperature increases from 40 to $60^{\circ} \mathrm{C}$. However, a further increase in temperature caused a reduction in conversion to $79.56 \%$ at $70^{\circ} \mathrm{C}$. This result can be explained as enzyme thermal deactivation and denaturation with a rise in temperature beyond a certain limit that leads to destruction of weak bonds that determine the enzyme three dimensional structures. Since the temperature increases the reaction rate also increases, due to increased kinetic energy of molecule that may assist effective interaction and collisions between substrate and enzymes [8]. However, it was noticed that at $70^{\circ} \mathrm{C}$, the final conversion was poorer than the $60^{\circ} \mathrm{C}$, as lipase may be denatured at higher temperatures. While enzymes are exposed for an extended period at very high temperature may lose their active conformation and suffer thermal deactivation. Actually, lipase B is known to withstand higher temperatures, but the enzyme inactivation rate is quicker with time. Here, the lipase shows stability at $60^{\circ} \mathrm{C}$ with excellent conversion. Therefore, $60^{\circ} \mathrm{C}$ was considered as an optimum temperature for further synthesis of ester. Yadav and Dhoot also investigated the synthesis of cinnamyl laurate ester with $75 \%$ conversion in $2 \mathrm{~h}$ catalyzed by Novozym 435 at $60^{\circ} \mathrm{C}$ as the optimum temperature [18]. 


\subsection{Effect of catalysts}

From an economic point of view, the study of enzyme loading is a very important factor due to the higher cost of the enzyme. To achieve remarkable reactivity and stability, the lipases are immobilized on spongy support, which increases the cost of enzyme. Hence, by considering the advantages of immobilized lipase $B$; it is necessary to optimize the enzyme loadings concentration. The experiments were performed with $1.5 \%(\mathrm{w} / \mathrm{v})$ to $2.5 \%(\mathrm{w} / \mathrm{v})$ of total volume of reaction (substrate) mixture. It is noticed that with an increase in the amount of catalysts loading the conversion of propionic acid also increases with the relative active sites are available [24]. Figure 3 describes that the maximum conversion obtained at $2 \%(\mathrm{w} / \mathrm{v})$ enzyme loading is $87.89 \%$. Increased enzyme concentration causes interaction of reactant towards the enzyme and therefore, the rate of reaction increases with the conversion. However, beyond optimum solid concentration an increase in enzyme loading at $2.5 \%(\mathrm{w} / \mathrm{v})$, conversion was observed to be declined to $76.33 \%$. This would advise that limiting substrate molecules are all attached to the active sites of lipases, so further any increase in lipase loading will not have an influence on ester conversion due to unavailability of substrate molecules to react. Hence, beyond the optimum amount of lipase loading, there was no significant increase in ester conversion. Sometimes, the increase in the amount of lipase causes ineffective mixing, which bounds the mass transfer and efficient contact of enzyme and reactants, which leads to reduce ester conversion. At higher enzyme loading, the possibility of agglomeration

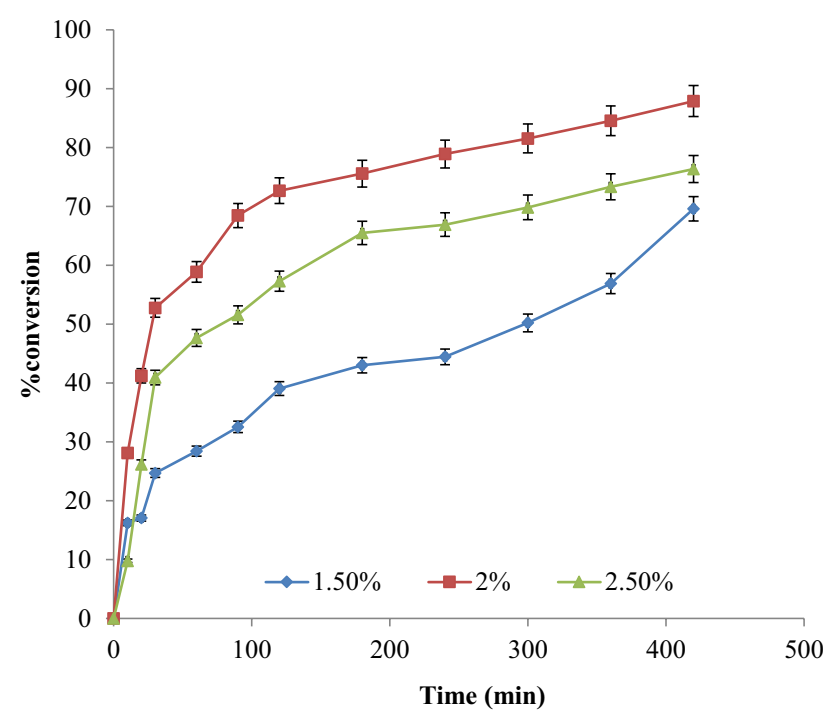

Fig. 3 Effect of catalyst on conversion of cinnamyl propionate: reaction conditions: molar ratio $1: 3$, temperature $60^{\circ} \mathrm{C}$, total volume is $23.08 \mathrm{~mL}$, speed of agitation $200 \mathrm{rpm}$; and molecular sieves $6 \%(\mathrm{w} / \mathrm{v})$

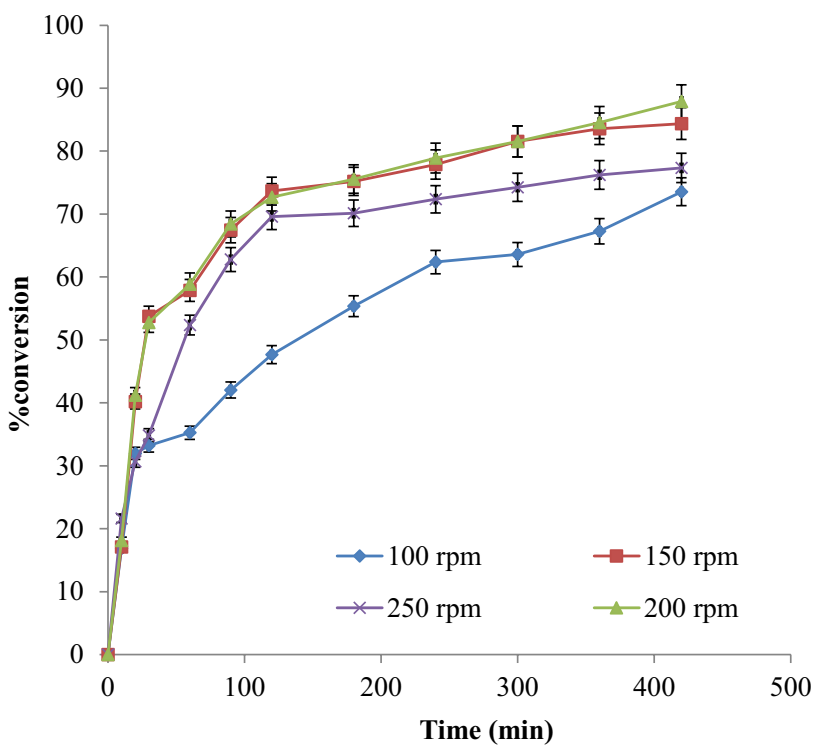

Fig. 4 Effect of agitation speed on conversion of cinnamyl propionate: reaction conditions: molar ratio $1: 3$, temperature $60{ }^{\circ} \mathrm{C}$, total volume is $23.08 \mathrm{~mL}$, enzyme loading $2 \%(\mathrm{w} / \mathrm{v})$, and molecular sieves $6 \%(\mathrm{w} / \mathrm{v})$

of immobilized lipase is also responsible for lower conversion [24]. Thus, the $2 \%(\mathrm{w} / \mathrm{v})$ loading of enzyme was taken into consideration as optimum and used for reaming sets of the experiment.

\subsection{Effect of speed of agitation}

To study the influence of speed of agitation on cinnamyl propionate ester conversion, experiments were performed by varying it in the range of $100-250 \mathrm{rpm}$. As the agitation speed increased from 100 to $200 \mathrm{rpm}$, the ester conversion was observed to be increased from 73.55 to $87.89 \%$ (Fig. 4). In heterogeneous enzymatic reaction, the substrate has to diffuse from liquid bulk to surface and then diffuse through interior pores of catalyst to reach the active site, where the real reaction is taking place and the product is formed. Further, it is needed to remove the product from the enzyme active sites of particles. By performing reaction at optimum speed, the limitation for external mass transfer can be minimized. Beyond optimum value, the results found to be slightly declined that can be reasoned by shear force impact on lipase B due to the removal of enzyme from support. Also, the reaction mixture converted to muddy at higher agitation speed, which indicates that enzyme was physically damaged at higher speed and lost its activity; sometimes, the enzymes splashes towards the wall of the reactor and damages the enzymes at a higher speed. Similar results were stated for the enzymatic synthesis of butyl caprylate ester with $92 \%$ conversion obtained for $60^{\circ} \mathrm{C}$ after $5 \mathrm{~h}$, at $2 \%(\mathrm{w} / \mathrm{v})$ catalyst 
loading, 1:2 molar ratios of caprylic acid and n-butanol, and agitation speed as $250 \mathrm{rpm}$ [25]. Hence, the $200 \mathrm{rpm}$ stirring speed was selected as optimum for the synthesis of ester cinnamyl propionate in solvent free system keeping all other parameters constant.

\subsection{Reusability of lipase}

The immobilized enzymes can be reused and recycled if the bio-catalyst activity is recollected or maintained. The reusability study is most important to determine its application at the industrial scale, especially with respect to the cost of the process. So it becomes essential to make better use of the expensive lipase and use it several times. For enzyme reuse, after the reaction, the enzymes were separated using filtration, thoroughly washed with hexane, and reused. Washing with hexane can release the substrates deposited on the surface of enzymes, product residue, and some water content abide by active sites of lipase if engaged, which obstructs its activity and reduces

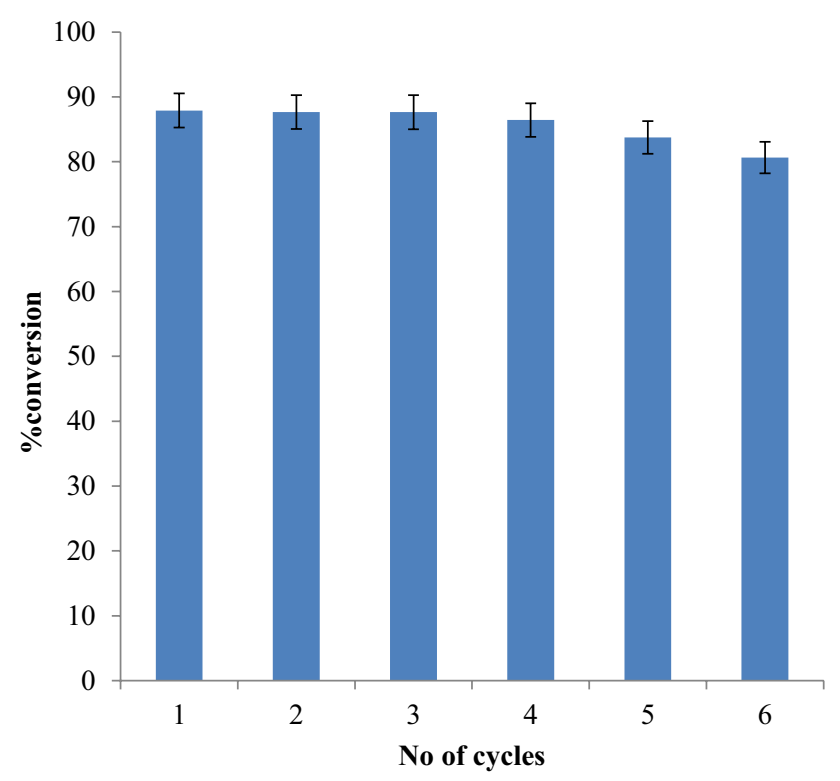

Fig. 5 Effect of reusability of catalyst on conversion of cinnamyl propionate: reaction conditions: molar ratio $1: 3$, temperature $60^{\circ} \mathrm{C}$, total volume is $23.08 \mathrm{~mL}$, enzyme loading $2 \%(\mathrm{w} / \mathrm{v})$, speed of agitation $200 \mathrm{rpm}$; and molecular sieves $6 \%(\mathrm{w} / \mathrm{v})$ the ester conversion. The reusability experiments were performed at acid to alcohol 1:3 molar ratio, temperature $60{ }^{\circ} \mathrm{C}, 2 \%(\mathrm{w} / \mathrm{v})$ enzyme loading, and $200 \mathrm{rpm}$ stirring agitation speed with $6 \%(\mathrm{w} / \mathrm{v})$ molecular sieves. Figure 5 depicts that enzyme can be recycled 6 times with a marginal decrease in enzyme activity and conversion after 6th cycle. For fresh Fermase enzyme; the initial activity was calculated as $9.15 \mathrm{U}$. In the reusability study, the initial activity decreases after $1 \mathrm{st}, 2 \mathrm{nd}, 3 \mathrm{rd}, 4$ th, 5 th, 6 th cycle to $8.75,8.11,7.67,7.12,6.83,6.45 \mathrm{U}$ respectively. The washing with $\mathrm{n}$-hexane was the best treatment and allowed the enzyme to retain around $70 \%$ of its activity even after 6 reaction batches. Thus, enzyme verified to be fruitful in the synthesis of flavor and fragrance as no formation of by-product, lower energy consumption for product purification, and use of milder reaction conditions without solvent process. Martins et al. also found that Novozym 435 could be recycled for 6 successive cycles for butyl acetate synthesis at temperature $45^{\circ} \mathrm{C}$, and $70 \%$ of its initial activity was maintained by washing enzyme with hexane and reused [26]. Thus, washing with hexane before successive cycle confirmed to improve productivity and performance of fermase CALB $^{\mathrm{TM}} 10000$ for the synthesis of cinnamyl propionate in solvent free condition.

\subsection{Determination kinetic constant}

Commonly, lipases are known to proceed with mechanism ping pong bi-bi kinetics. The enzyme catalyzed reaction mechanism can be understood by its kinetics that further helps to improve or enhance the conversion of ester. By using the enzyme, the reactions were carried out to synthesis short chain ester with Michaelis-Menten assumptions further modified into ping pong bi-bi model. Two different substrates are involved in the reaction that entitled bi-substrate enzymatic reaction. Sequential and Ping pong mechanisms are accepted enzymatic mechanisms for the bi-substrate reaction. Fermase CALB ${ }^{\text {TM }} 10000$ is used to precede kinetics with model random bi-bi through competitive inhibition by acyl donor or acceptor. The attached compound to enzyme affecting its initial activity is known as a lipase inhibitor. They are universal as competitive, non-competitive, and uncompetitive inhibitions. The

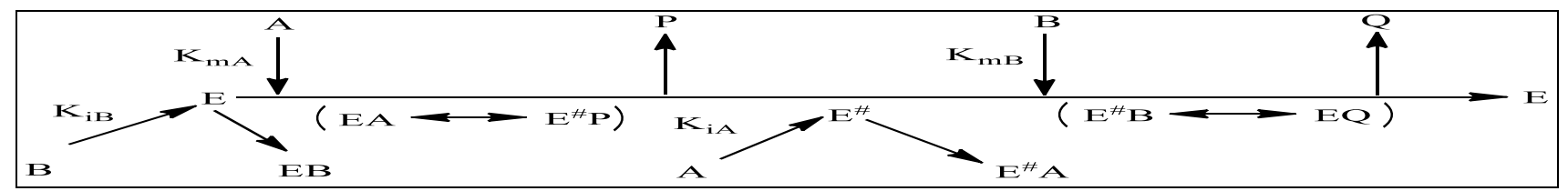

Scheme 1 The ping-pong bi-bi mechanism for the esterification reaction 
model ping pong bi-bi is well known for bi-substrates enzymatic reaction, and it is represented in Scheme 1.

Initially, the moiety of (EA) enzyme-acid complex is formed by Acid (A) combines with Enzyme (E). The enzyme-acid complex isomerizes to intermediate enzyme acyl ( $\left.E^{*}\right)$ and by-product water $(\mathrm{P})$ released first as a product. Now the alcohol (B) binds and form other acid-alcohol-enzyme complex $\left(E^{*} B\right)$ that ultimately releases the ester product and free enzyme (E). In this work, the different acid to alcohol molar ratios were taken into consideration ranging from 1:1 to 1:4, and the impact of acid and alcohol concentration on initial reaction rates were studied. The experiments were carried out, and samples were taken at 20 min interval to evaluate the initial rate and ester conversion. It was noticed that conversion achieved in $1 \mathrm{~h}$ is $20 \%$, and later, we can consider that the impact of the presence of a product in terms of inhibition is minor. As per the equation of the ping pong bi-bi mechanism model, various reaction parameters were studied by nonlinear lapse with the smallest sum of errors (SSE) method. The simple ping pong bi-bi mechanism rate equation can be expressed as

$V=\frac{V_{\max }[A][B]}{K_{a}[A]+K_{b}[B]+[A][B]}$

Overall, it is observed that for the different reactions catalyzed by lipase (transesterification, esterification, and inter-esterification), the most widely accepted catalytic action of the enzyme is described by ping pong bi-bi mechanism. This kinetic model by inhibition is regularly utilized for experimental data in lipase-catalyzed reaction. The kinetic model fitting of the above-mentioned enzymatic reactions was performed using three model mechanisms with experimental data, ordered bi-bi, ping pong bi-bi, and random bi-bi. In random bi-bi mechanism either any substrate may bind first followed by the other substrate (Scheme 2). In this mechanism, all possible binary substrate-enzyme and enzyme-product complexes are rapidly formed reversibly when the enzyme is added to a reaction mixture containing $A, B, P$ and $Q$ (Here $A$ and $B$ are the substrates, $\mathrm{P}$ and $\mathrm{Q}$ are the products).

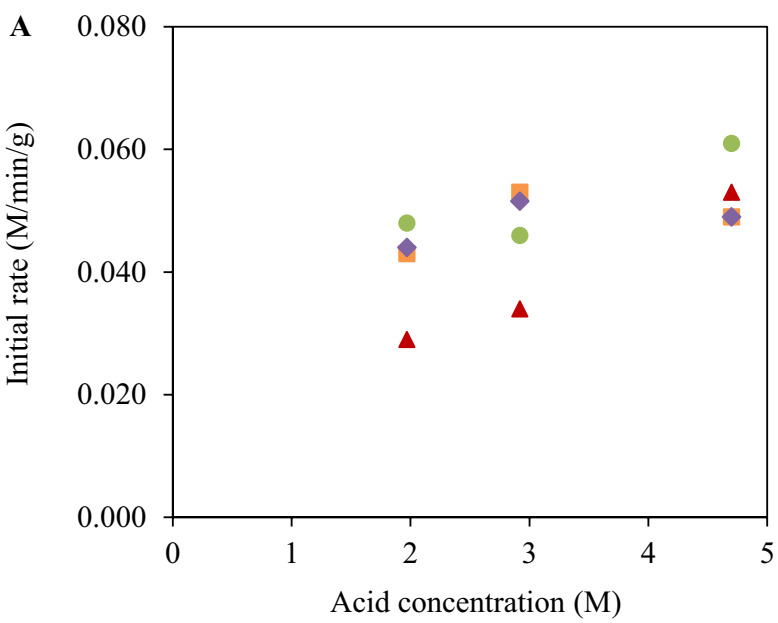

$\begin{array}{ll}\text { Experimental } & \Delta \text { Ping Pong bi-bi } \\ - \text { Ordered bi-bi } & \diamond \text { Random bi-bi }\end{array}$

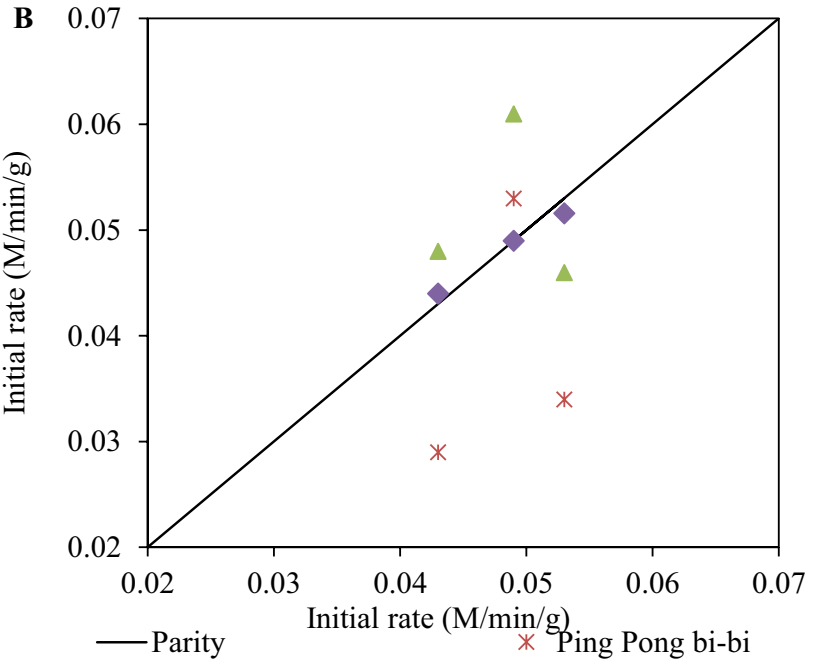

$\Delta$ Ordered bi-bi $\quad \diamond$ Random bi-bi

Fig. 6 a Comparison of initial rate versus acid concentration in case of all three models with experimental results and $\mathbf{b}$ parity plot of predicted rate versus experimental rate

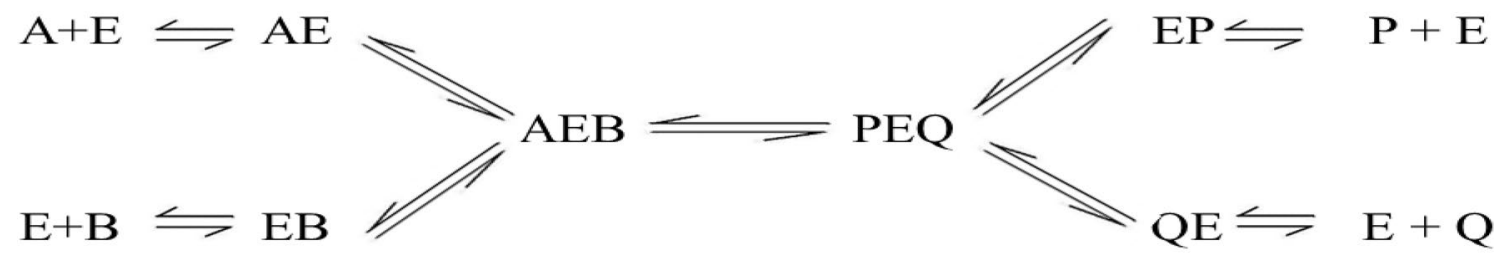

Scheme 2 The random bi-bi mechanism for esterification reaction 
Table 1 Values of the kinetic parameters for random Bi Bi mechanism with dead-end inhibition by propionic acid

\begin{tabular}{llll}
\hline Kinetic constant & \multicolumn{3}{l}{ Kinetic models } \\
\cline { 2 - 4 } & $\begin{array}{l}\text { Random } \\
\text { bi-bi }\end{array}$ & $\begin{array}{l}\text { Ping pong } \\
\text { bi-bi }\end{array}$ & $\begin{array}{l}\text { Ordered } \\
\text { bi-bi }\end{array}$ \\
\hline $\begin{array}{l}\mathrm{V}_{\text {max }}(\mathrm{M} / \mathrm{min} / \mathrm{g} \\
\text { catalysts })\end{array}$ & 231.86 & 129.60 & 30.671 \\
$\mathrm{~K}_{\mathrm{a}}(\mathrm{M})$ & 0.049 & 0.129 & 0.0141 \\
$\mathrm{~K}_{\mathrm{b}}(\mathrm{M})$ & 422.9 & 0.0009 & 0.0008 \\
$\mathrm{~K}_{\text {ia }}(\mathrm{M})$ & 32.43 & 41.54 & 21.91 \\
$\mathrm{~K}_{\text {ib }}(\mathrm{M})$ & - & $9.21 \mathrm{E}-03$ & - \\
$\mathrm{Ki}(\mathrm{M})$ & - & - & 0.000162 \\
$\mathrm{SSE}$ & 0.0001 & 0.0007 & 0.00096 \\
\hline
\end{tabular}

The initial rates were used to calculate the ester conversion by using the following random bi-bi model equation.

$V_{o}=\frac{V_{\max }[A][B]}{K_{a}[A]+K_{b}[B]+[A][B]+K_{i a} K_{b}}$

Figure $6 a$ illustrates the initial rate of reaction with respect to initial acid concentration. From the figure, it can be seen that the initial rate of reaction increases with a corresponding increase in acid concentration from 1.97 to $2.97 \mathrm{M}$. The initial rate reaches to a maximum of nearly $0.052 \mathrm{M} / \mathrm{min} / \mathrm{g}$-enzymes, and after that, it showed a fall. This can be attributed to inhibition of enzyme at high concentrations. However, the final conversion obtained was $87.89 \%$ at $2.97 \mathrm{M}$ acid concentration. The literature includes a scientific variety of mechanisms to elucidate the enzyme catalyzed reaction kinetics reported by Khan et al. [19]. For valuation, the selection of mechanism depends on the elements like total substrates, catalyst inhibition, etc. Consequently, the ping pong bi-bi kinetic model with inhibition is commonly used to model the experimental data in enzyme catalyzed esterification. But in this case, random bi-bi kinetic model gives a good fit, which can be seen from parity Fig. $6 \mathrm{~b}$ and Table 1. It is clear from Fig. 6a, $\mathrm{b}$ that the ping pong bi-bi and ordered bi-bi do not show $a$ good fit, but the random bi-bi model shows a good fit. The various parameters were evaluated by examining initial rates as per above velocity formulae by using non-linear regression with the sum of square errors (SSE) minimization applied using Microsoft Excel 2010 and the model parameters were considered. Random bi-bi model showed good fit, with the kinetic parameters; $V_{\max }=231.86 \mathrm{M} /$ $\mathrm{min} / \mathrm{g}$ catalysts, $\mathrm{K}_{\mathrm{a}}=0.049 \mathrm{M}, \mathrm{K}_{\mathrm{b}}=422.80 \mathrm{M}, \mathrm{K}_{\mathrm{ia}}=32.43 \mathrm{M}$, and $S S E=0.0001$. The sum of the square value for random bi-bi mechanism is very less as compared to ping pong bi-bi and ordered bi-bi mechanism. In our experimentations, the use of molecular sieves helped in withdrawing deposits of water hence avoiding hydrolysis and giving higher initial rates when cinnamyl alcohol binds with enzyme and dead end-complex formed that shows inhibitory action of alcohol. But, as understood from Fig. 6a, even a certain amount of acid shows inhibitory action at greater concentration. The $\mathrm{V}_{\max }$ high value indicates that there is a superior affinity for reactant-enzyme complex to produce and splitting product. The value of $\mathrm{K}_{\mathrm{a}}$ and $\mathrm{K}_{\mathrm{b}}$ indicates that reduced affinity of the enzyme towards reactant and $\mathrm{K}_{\mathrm{ia}}$ high value indicates that there is improved binding to non-catalytic position leading to inhibition. The reactant $A$ shows more affinity towards the enzyme, causing the formation of complex, and reactant $B$ showed less affinity for the enzyme.

\subsection{Determination of thermodynamic parameters}

For evaluating the thermodynamic constants and study of kinetic data, the activation energies were calculated for the esterification reaction catalyzed by enzyme fermase CALB $^{\mathrm{TM}} 10000$ using the Arrhenius equation at different temperatures. To establish equilibrium, all reactions need energy that can be expressed for both product and reactants involved in reaction through Gibbs free energy $(\mathrm{G})$, enthalpy $(\mathrm{H})$, and entropy (S). For the formation of ES (substrate-enzyme complex) transition state in esterification, reactant molecules required positive energy to overcome the energy barrier, which is known as activation energy, and it is denoted by $E_{a}$.

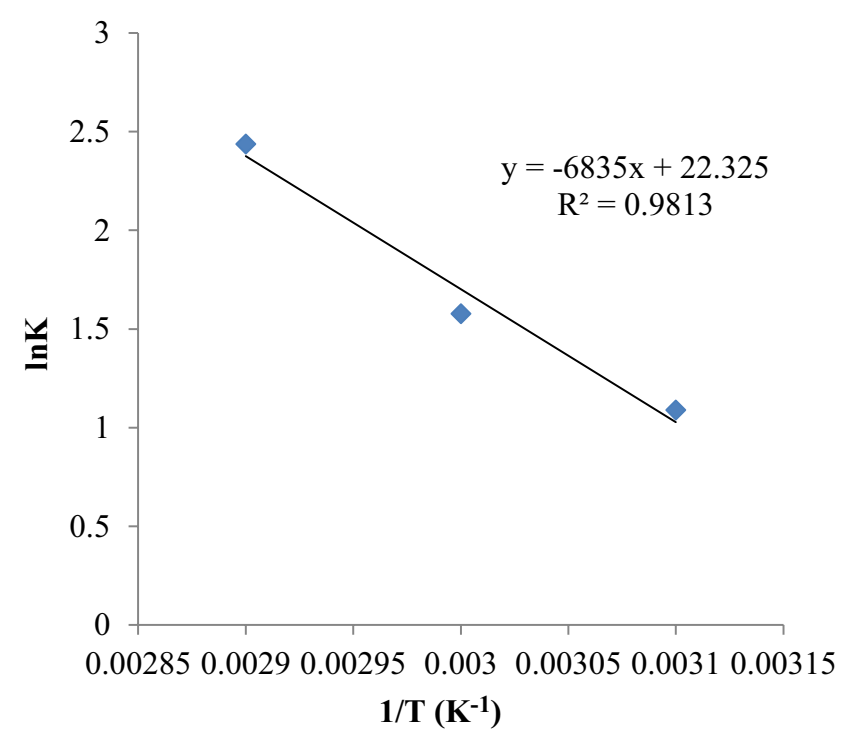

Fig. 7 Arrhenius plot in without solvent condition catalyzed by fermase $10000^{\mathrm{TM}}$ CALB in stirred batch reactor system at molar ratio $1: 3$, temperature $60^{\circ} \mathrm{C}$, total volume is $23.08 \mathrm{~mL}$, enzyme loading $2 \%(\mathrm{w} / \mathrm{v})$, speed of agitation $200 \mathrm{rpm}$; and molecular sieves $6 \%$ $(w / v)$ 
Table 2 Thermodynamic parameters in enzymatic reaction by conventional system for the synthesis of cinnamyl propionate

\begin{tabular}{lllll}
\hline Parameters & Units & \multicolumn{4}{l}{ Temp (K) } \\
\cline { 3 - 5 } & & 313 & 323 & 333 \\
\hline $\mathrm{K}$ & - & 0.0065 & 0.0081 & 0.0097 \\
Enthalpy $(\Delta \mathrm{H})$ & $\left(\mathrm{kJ} \mathrm{mol}^{-1}\right)$ & 16.97 & 16.93 & 16.49 \\
Entropy $(\Delta \mathrm{S})$ & $\left(\mathrm{kJ} \mathrm{mol}^{-1} \mathrm{~K}^{-1}\right)$ & -0.289 & -0.287 & -0.286 \\
Gibb's free energy $(\Delta \mathrm{G})$ & $\left(\mathrm{kJ} \mathrm{mol}^{-1}\right)$ & 105.3 & 108.5 & 111.3 \\
\hline
\end{tabular}

Here, at different temperatures, $313-333 \mathrm{~K}$ rate data were obtained with $2 \%(\mathrm{w} / \mathrm{v})$ enzyme loading, molar ratio 1:3 propionic acid to cinnamyl alcohol, molecular sieves $6 \%(\mathrm{w} / \mathrm{v})$ and agitation speed at $200 \mathrm{rpm}$. The relative temperature reliant on rate constant can be determined by using the Arrhenius equation. The Arrhenius graph of $\ln (k)$ versus $1 / T$ is illustrated in Fig. 7. The calculated value of (Ea) activation energy at varying temperature is positive in terms of enzymatic esterification reaction. It is obtained as $21.56 \mathrm{~kJ} / \mathrm{mol}$, which is close to the reported activation energy for fatty acids esterification reaction i.e. $22.8 \mathrm{~kJ} / \mathrm{mol}$ with lipase $B$ Pseudomonas cepacia and $24.9 \mathrm{~kJ} / \mathrm{mol}$ with Thermomyces lanuginosus lipase [27]. Mohmud et al. [28] showed similar activation energy using Novozym 435 from Aspergillus Niger as a bio-catalyst in oleic acid esterification reaction. Enzymes have a tendency to increase reaction rate from substrate and enzyme collision and interaction by lowering the activation energy, and stabilize the transition state. The rate constant observed at $333 \mathrm{~K}$ was reduced due to the possibility of enzyme thermal deactivation at a higher temperatures. The thermodynamic parameters are calculated and stated in Table 2. The entropy loss during substrate-enzyme complex formation [ES] with release of translational and rotational energies, and consequently, the negative entropy stated at $323 \mathrm{~K}$ is $-0.2871 \mathrm{~kJ} / \mathrm{mol} \mathrm{K}$. This implied that formation of substrate-enzyme complex is spontaneous as generally result of effective collisions. The negative value of $\Delta S$ indicates that the product is more ordered as compared to the reaction. At different temperatures, $\Delta \mathrm{G}$ evaluated

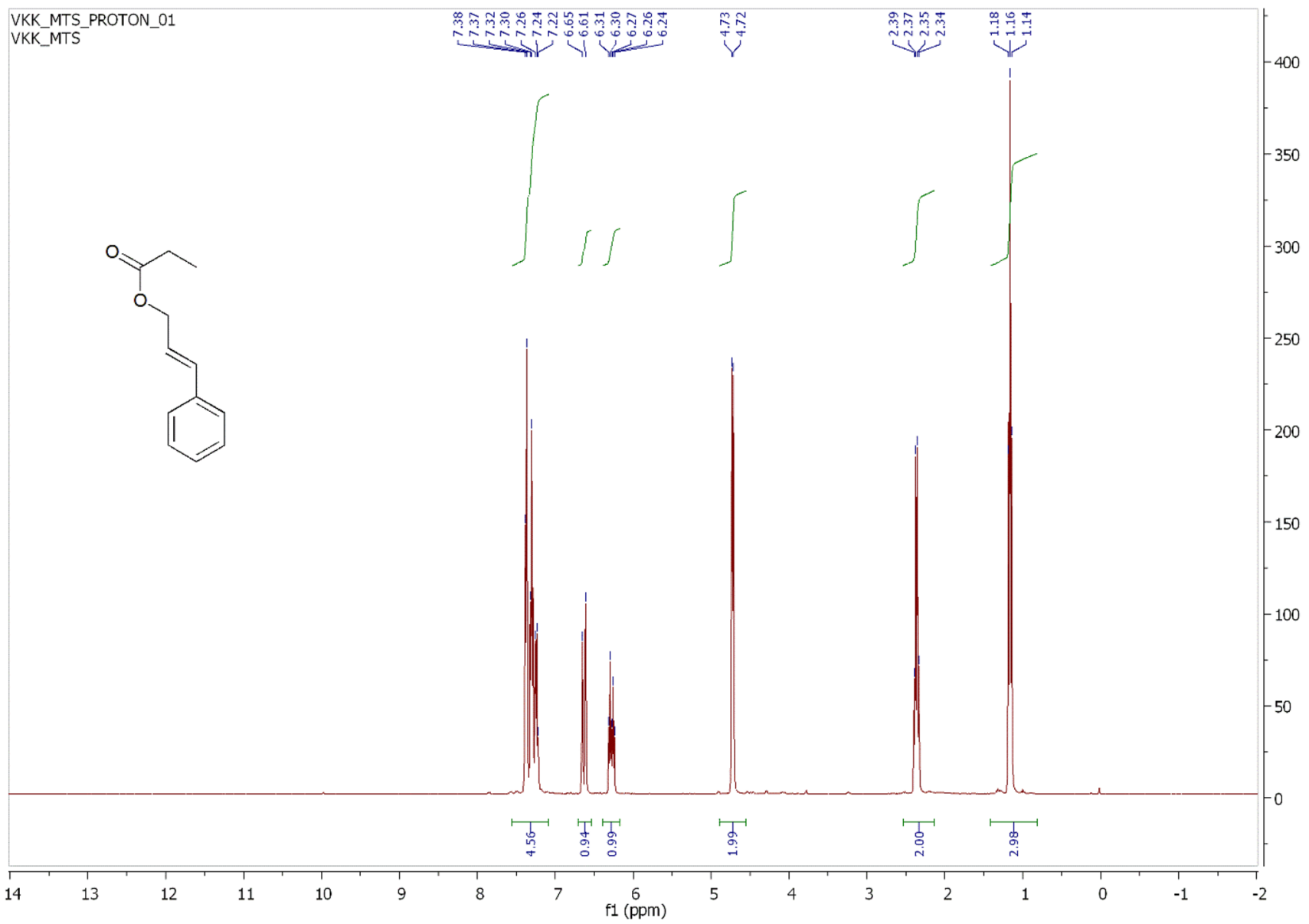

Fig. 8 1H NMR Full spectra of cinnamyl propionate in the presence of chloroform $\left(400 \mathrm{MHz}, \mathrm{CDCl}_{3}\right.$ at $\left.25^{\circ} \mathrm{C}\right)$ 
is nearly similar in the range between 105 and $115 \mathrm{~kJ} /$ mol $[29,30]$. The positive value of $\Delta \mathrm{G}$ indicates that the reaction was non-spontaneous in nature. The positive value of $\Delta \mathrm{H}$ shows that external heat is required to carry the reactants towards the transition state so as to form the products. The reaction temperature shows great influence on the rate of esterification reaction, therefore, a suitable reaction temperature needs to be selected for maximum conversion of ester.

\subsection{Product characterization}

The cinnamyl propionate product formation was confirmed using ${ }^{1} \mathrm{H}$ NMR spectra and represented in Fig. 8. The ${ }^{1} \mathrm{H}$ NMR chemical shift for the cinnamyl propionate are as follows, ${ }^{1} \mathrm{H}$ NMR $\left(400 \mathrm{MHz}, \mathrm{CDCl}_{3}\right) \delta 7.38-7.22(\mathrm{~m}$, $5 \mathrm{H}), 6.65-6.61(\mathrm{~d}, 1 \mathrm{H}, \mathrm{J}=16), 6.31-6.24(\mathrm{~m}, 1 \mathrm{H}), 4.73-4.72$ $(d, 2 H, J=4), 2.39-2.34(d, 2 H, J=8), 1.18-1.14(t, 3 H$, $J=8)$.

\section{Conclusion}

The cinnamyl propionate was synthesized successfully under no solvent condition, using propionic acid and cinnamyl alcohol as a reactant in the presence of fermase $C^{A L B}{ }^{\text {TM }} 10000$ from Candida antarctica lipase B catalyst. Also, the study involved optimization of reaction parameters comprising the influence of temperature, mole ratio, enzyme loadings, agitation speed, and reusability of enzymes. Maximum conversion of $87.89 \%$ was observed at $60^{\circ} \mathrm{C}$ temperature, $1: 3$ acid to alcohol ratio, $2 \%$ enzyme loading, and 200 agitation speed after $7 \mathrm{~h}$ of reaction time. The random bi-bi model gives a good fit by using non-linear regression with the sum of square errors (SSE) minimization method. The enzyme was very effective as it was recycled six times with the minimum loss of activity. For the esterification reaction, the activation energy was evaluated as $21.56 \mathrm{~kJ} / \mathrm{mol}$. The thermodynamic parameters predict the non-spontaneous and endothermic nature of enzymatic synthesis of cinnamyl propionate. The molecular sieves show an effective alternative to adsorb the water formed during the process in the reaction mixture. Since all the reactions were performed in a solvent-free medium, the drawbacks linked with the use of organic solvent were practically omitted.

\section{Compliance with ethical standards}

Conflict of interest The authors declare that they have no conflict of interests.

\section{References}

1. Mahapatra P, Kumari A, Kumar Garlapati V, Banerjee R, Nag A (2009) Enzymatic synthesis of fruit flavor esters by immobilized lipase from Rhizopus oligosporus optimized with response surface methodology. J Mol Catal B Enzym 60:57-63

2. Zaidi $A$ et al (2002) Esterification of fatty acids using nylonimmobilized lipase in $n$-hexane: kinetic parameters and chainlength effects. J Biotechnol 93:209-216

3. Shintre MS, Ghadge RS, Sawant SB (2002) Kinetics of esterification of lauric acid with fatty alcohols by lipase: effect of fatty alcohol. J Chem Technol Biotechnol 77:1114-1121

4. Ghamgui H, Karra-Chaâbouni M, Gargouri Y (2004) 1-Butyl oleate synthesis by immobilized lipase from Rhizopus oryzae: a comparative study between $n$-hexane and solvent-free system. Enzyme Microb Technol 35:355-363

5. Paludo N, Alves JS, Altmann C, Ayub MAZ, Fernandez-Lafuente $R$, Rodrigues RC (2015) The combined use of ultrasound and molecular sieves improves the synthesis of ethyl butyrate catalyzed by immobilized Thermomyces lanuginosus lipase. Ultrason Sonochem 22:89-94

6. Dange PN, Kulkarni AV, Rathod VK (2015) Ultrasound assisted synthesis of methyl butyrate using heterogeneous catalyst. Ultrason Sonochem 26:257-264

7. Ahammad TR, Gomes SZ, Sreekrishnan J (2008) Wastewater treatment forproduction of $\mathrm{H}_{2} \mathrm{~S}$-free biogas. J Chem Technol Biotechnol 83:1163-1169

8. Gawas SD, Lokanath N, Rathod VK (2018) Optimization of enzymatic synthesis of ethyl hexanoate in a solvent free system using response surface methodology (RSM). Biocatalysis $4: 14-26$

9. Chowdary GV, Ramesh MN, Prapulla SG (2000) Enzymic synthesis of isoamyl isovalerate using immobilized lipase from Rhizomucor miehei: a multivariate analysis. Process Biochem 36:331-339

10. Hari Krishna S, Divakar S, Prapulla SG, Karanth NG (2001) Enzymatic synthesis of isoamyl acetate using immobilized lipase from Rhizomucor miehei. J Biotechnol 87:193-201

11. Bansode SR, Rathod VK (2014) Ultrasound assisted lipase catalysed synthesis of isoamyl butyrate. Process Biochem 49:1297-1303

12. Hari Krishna S, Karanth NG (2001) Lipase-catalyzed synthesis of isoamyl butyrate: a kinetic study. Biochim Biophys Acta Protein Struct Mol Enzymol 1547:262-267

13. Wu Z, Qi W, Wang M, Su R, He Z (2014) Lipase immobilized on novel ceramic supporter with $\mathrm{Ni}$ activation for efficient cinnamyl acetate synthesis. J Mol Catal B Enzym 110:32-38

14. Geng B, Wang M, Qi W, Su R, He Z (2012) Cinnamyl acetate synthesis by lipase-catalyzed transesterification in a solventfree system. Biotechnol Appl Biochem 59:270-275

15. Gupta C, Prakash D, Gupta S (2015) A biotechnological approach to microbial based perfumes and flavours. J Microbiol Exp 2:1

16. Tomke PD, Rathod VK (2015) Ultrasound assisted lipase catalysed synthesis of cinnamyl acetate via transesterification reaction in a solvent free medium. Ultrason Sonochem 27:241-246

17. Gandhi NN, Sawant SB, Joshi JB (1995) Studies on the lipozymecatalyzed synthesis of butyl laurate. Biotechnol Bioeng 46:1-12

18. Yadav GD, Dhoot SB (2009) Immobilized lipase-catalysed synthesis of cinnamyl laurate in non-aqueous media. J Mol Catal B Enzym 57:34-39

19. Khan NR, Jadhav SV, Rathod VK (2015) Lipase catalysed synthesis of cetyl oleate using ultrasound: optimisation and kinetic studies. Ultrason Sonochem 27:522-529 
20. Syamsul KMW, Salina MR, Siti SO, Hanina MN, Basyaruddin MAR, Jusoff K (2010) Green synthesis of lauryl palmitate via lipasecatalyzed reaction. World Appl Sci J 11:401-407

21. Garcia T, Coteron A, Martinez M, Aracil J (2000) Kinetic model for the esterification of oleic acid and cetyl alcohol using an immobilized lipase as catalyst. Chem Eng Sci 55:1411-1423

22. Panpipat W, Xu X, Guo Z (2013) Improved acylation of phytosterols catalyzed by Candida antarctica lipase A with superior catalytic activity. Biochem Eng J 70:55-62

23. Patidar P, Mahajani SM (2013) Esterification of fusel oil using reactive distillation. Part II: process alternatives. Ind Eng Chem Res 52:16637-16647

24. van Beilen JB, Li Z (2002) Enzyme technology: an overview. Curr Opin Biotechnol 13:338-344

25. Sose MT, Bansode SR, Rathod VK (2017) Solvent free lipase catalyzed synthesis of butyl caprylate. J Chem Sci 129:1755-1760

26. Martins AB, Graebin NG, Lorenzoni ASG, Fernandez-lafuente R, Ayub MAZ, Rodrigues RC (2011) Rapid and high yields of synthesis of butyl acetate catalyzed by Novozym 435: reaction optimization by response surface methodology. Process Bichem 46:2311-2316
27. Sharma A, Dalai AK, Chaurasia SP (2015) Thermodynamic study of hydrolysis and esterification reactions with immobilized lipases. Eur Int J Sci Technol 4:128-136

28. Mahmud MS, Safinski T, Nelson MI, Sidhu HS, Adesina AA (2010) Kinetic analysis of oleic acid esterification using lipase as catalyst in a microaqueous environment. Ind Eng Chem Res 49:1071-1078

29. Gawas SD, Rathod VK (2018) Enhancement in synthesis of ethyl laurate catalyzed by fermase by combined effect of ultrasound and stage wise addition of ethanol. Chem Eng Process 125:207-213

30. Demmacarà $P$, Ciriminna R, Shiju NR, Rothenberg G, Pagliaro M (2014) Enhanced heterogeneous catalytic conversion of furfuryl alcohol into butyl levulinate. ChemSusChem 7:835-840

Publisher's Note Springer Nature remains neutral with regard to jurisdictional claims in published maps and institutional affiliations. 